ORIGINAL ARTICLE

\title{
Acute toxicity of a deltamethrin based pesticide (DBP) to the Neotropical electric fish Microsternarchus cf. bilineatus (Gymnotiformes)
}

\author{
Valesca de Souza CHAVES ${ }^{1 *} \oplus$, Jaydione Luiz MARCON², Wallice Paxiúba DUNCAN³, \\ José Antônio ALVES-GOMES ${ }^{4}$ \\ Instituto Nacional de Pesquisas da Amazônia - INPA, Programa de Pós-Graduação em Biologia de Água Doce e Pesca Interior, Av. André Araújo 2936, Petrópolis, \\ 69067-375 Manaus, Amazonas, Brazil \\ 2 Universidade Federal do Amazonas - UFAM, Instituto de Ciências Biológicas, Departamento de Ciências Fisiológicas. Av. Gen. Rodrigo Octávio 6200, Coroado I. \\ 69080-900, Manaus, AM, Brazil \\ 3 Universidade Federal do Amazonas - UFAM, Instituto de Ciências Biológicas, Departamento de Morfologia. Av. Gen. Rodrigo Octávio, 6200, Coroado I. 69080-900, \\ Manaus, AM, Brazil \\ ${ }^{4}$ Instituto Nacional de Pesquisas da Amazônia - INPA, Laboratório de Fisiologia Comportamental e Evolução, Av. André Araújo 2936. Petrópolis, 69067-375 Manaus, \\ Amazonas, Brazil \\ * Corresponding author: chaves.valesca@gmail.com; (D) https://orcid.org/0000-0001-9540-3408
}

\section{ABSTRACT}

Deltamethrin is a pyrethroid insecticide widely used in pest control in Brazilian agriculture. The intensive and disordered use of this pesticide in the Amazon region can drive it into aquatic ecosystems in several ways, but mainly by runoff and leaching. The present study was conceived to determine the acute toxicity $\left(\mathrm{LC}_{50}\right)$ of a deltamethrin based pesticide (DBP) and to characterize its effects on two biochemical biomarkers, glutathione-S-transferase (GST) and acetylcholinesterase (AChE), in tissues of the electric fish Microsternarchus cf. bilineatus. Fishes were exposed to concentrations of 1, 2, 3, 4 and $5 \mu \mathrm{g} \mathrm{L}^{-1}$ of DBP for up to 96 hours. For each treatment, the absolute activity of the enzymes GST (muscle and liver) and AChE (muscle and nervous tissue) were analyzed. The $\mathrm{LC}_{50}-96 \mathrm{~h}$ for Microsternarchus cf. bilineatus was $2.15 \mu \mathrm{g} \mathrm{L}{ }^{-1}$, the lowest concentration registered for an Amazonian fish species so far. None of the concentrations tested of this insecticide affected AChE activity for the exposure period tested. A significant increase in muscle GST activity was detected only for concentrations of 2 and $3 \mu g \mathrm{~L}^{-1}$.

KEYWORDS: pyrethroid insecticide, biomarkers, median $\mathrm{LC}_{50}$, glutathione-S-transferase, acetylcholinesterase

\section{Toxicidade aguda de um pesticida à base de deltametrina (PBD) no peixe elétrico neotropical Microsternarchus cf. bilineatus (Gymnotiformes)}

\section{RESUMO}

A deltametrina é um inseticida piretróide amplamente utilizado no controle de pragas na agricultura brasileira. O uso intensivo e desordenado desse pesticida na Amazônia pode carreá-lo aos ecossistemas aquáticos de várias maneiras, mas principalmente por escoamento e lixiviaçáo. $\mathrm{O}$ presente estudo foi concebido para determinar a toxicidade aguda $\left(\mathrm{LC}_{50}\right)$ de um pesticida à base de deltametrina $(\mathrm{PBD})$ e caracterizar seus efeitos sobre dois biomarcadores bioquímicos, a glutationa-S-transferase (GST) e a acetilcolinesterase (AChE), em tecidos do peixe elétrico Microsternarchus cf. bilineatus. Os peixes foram expostos a concentraçôes de 1, 2, 3, 4 e $5 \mu \mathrm{g} \mathrm{L} \mathrm{L}^{-1}$ de PBD por até 96 horas. Para cada tratamento, foi analisada a atividade absoluta das enzimas GST (músculo e fígado) e AChE (músculo e tecido nervoso). A $\mathrm{CL}_{50}-96 \mathrm{~h}$ para Microsternarchus cf. bilineatus foi de $2,15 \mu \mathrm{g} \mathrm{L}^{-1}$, a menor concentraçáo registrada para um peixe amazônico até o momento. Nenhuma das concentraçóes testadas deste inseticida afetou a atividade da AChE para o período de exposiçáo testado. Um aumento significativo da atividade de GST no músculo foi detectado somente para as concentraçóes de 2 e $3 \mu \mathrm{g} \mathrm{L} \mathrm{L}^{-1}$.

PALAVRAS-CHAVE: inseticida piretróide, biomarcadores, $\mathrm{CL}_{50}$ mediana, glutationa-S-transferase, acetilcolinesterase 


\section{INTRODUCTION}

Deltamethrin is a synthetic type II pyrethroid insecticide that acts on the central nervous system of its target organisms. It is considered very toxic to fishes due to its lipophilic character, allowing a high absorption rate through the gills (Santos et al. 2007). Among the eighteen pesticides used by farmers in the metropolitan region of Manaus, Amazonas State, Brazil, the deltamethrin insecticide was the most recurrent (Waichman et al. 2002, 2007).

The acute toxicity of deltamethrin was evaluated for several Amazonian fish species (Moraes et al. 2013; Souza et al. 2020), whit $\mathrm{LC}_{50}-96 \mathrm{~h}$ values ranging from 4 to 215 $\mu \mathrm{g} \mathrm{L}{ }^{-1}$, representing the lowest $\mathrm{LC}_{50}$ values among all tested pesticides and confirming the high toxicity of this pyrethroid to Amazonian fish. Biochemical and physiological effects of deltamethrin and other pesticides largely used in Brazil, such as glyphosate, have also been reported for other teleost species, particularly regarding their effect on the activity of glutathione S-transferase (GST) and acetylcholinesterase (AChE) (Bálint et al. 2007; Pimpao et al. 2007; Tu et al. 2012; Rossi 2013; Braz-Mota 2015; Elia et al. 2017).

GST is a phase II biotransformation enzyme that is extremely important in the detoxification mechanism of fishes, as it catalyzes the conjugation of reduced glutathione to xenobiotics or metabolites produced in phase I (Giulio and Hinton 2008). The activity of AChE has been widely used to evaluate the neurotoxic effects of pollutants (Bálint et al. 2007; Tu et al. 2012; Rossi 2013; Braz-Mota 2015). Its inhibition generates an accumulation of acetylcholine that results in a continuous and disordered transmission of nerve impulses (Soreq and Seidman 2001).

South American electric fish (order Gymnotiformes) have shown potential for use as model organisms for bioassays, with focus on the effect of different pollutants on the electric organ discharge (EOD) (Ferreira 2009; Moraes et al. 2013; Ferreira et al. 2015; Ferreira 2016; Nunes 2016). However, no data exist on the acute toxicity of any pesticide for a gymnotiform species. Gymnotiforms are present in almost all types of aquatic habitats in the Amazon and may represent up to $90 \%$ of the benthic fauna in the Amazon and Orinoco river basins (Hagedorn 1986; Alves-Gomes 1997; Marrero and Taphorn 1991). Among their most remarkable features is the electrogenic and electrosensory system (EES), formed by the electric organ and electroreceptors, which allows them to obtain information about their environment and to communicate (Bullock 1982; Alves-Gomes 2001). Physicochemical changes in water can alter the functioning of the EES, which makes this group very sensitive to pollutants in their environment (Hopkins 1974; Bullock et al. 1979; Alves-Gomes 2001; Ferreira 2009; Moraes et al. 2013; Ferreira et al. 2015; Ferreira 2016; Nunes 2016). Although GST and AChE have been widely used as molecular biomarkers in studies on environmental pollution (Bálint et al. 2007; Pimpao et al. 2007; Tu et al. 2012; Rossi 2013; Braz-Mota 2015; Elia et al. 2017), these enzymes have not yet been evaluated in Amazonian electric knifefish exposed to any pollutant.

For this study, the gymnotiform Microsternarchus cf. bilineatus was chosen due to its abundance in Amazonian streams, including the metropolitan region of Manaus, where it is exposed to the increasing use of pesticides. We evaluated the acute toxicity of a deltamethrin based pesticide (DBP) by determining the median lethal concentration $\left(\mathrm{LC}_{50}-96 \mathrm{~h}\right)$ and characterizing its effects on GST and AChE activity in muscle, liver and the nervous system of Microsternarchus cf. bilineatus.

\section{MATERIAL AND METHODS}

\section{Animal capture and maintenance}

Fishes were captured in September 2016 in a stream, Igarapé Tapuru (02433'8.1”S; 6057'39.5”W), an affluent of the Negro River, near the municipality of Novo Airão, Amazonas State, at about $180 \mathrm{~km}$ from the city of Manaus. Tapuru is a typical Amazonian terra firme forest stream of second to third order, with a relatively stable range of physicochemical properties throughout the year and a slightly acidic blackwater ( $\mathrm{pH} 4-5)$, low electrical conductivity $\left(<30 \mu \mathrm{S} \mathrm{cm}^{-1}\right)$ and an average annual temperature fluctuating between 25 and $27^{\circ} \mathrm{C}$ (J. Alves-Gomes, unpublished data). We collected 95 individuals of Microsternarchus cf. bilineatus weighing 0.89 $\pm 0.33 \mathrm{~g}$; and measuring $6.79 \pm 0.90 \mathrm{~cm}($ mean $\pm \mathrm{SD})$. This range of body lengths corresponds to adults and sub-adults, according to the sizes of mature individuals for species of this genus recorded in this region (J. Alves-Gomes, unpublished data). Capture of the animals was authorized by Instituto Chico Mendes de Conservaçâo da Biodiversidade (ICMBio) under license \# 55408-2, whereas the experimental procedures were performed according to the protocol approved by the Ethics Committee on Animal Reserach of Instituto Nacional de Pesquisas da Amazônia (CEUA/INPA protocol \# 020/2016).

We decided to adopt a conservative taxonomic treatment for the focal species Microsternarchus cf. bilineatus, due to recent findings regarding the taxonomy and systematics of the genus. For instance, molecular data has demonstrated that the previously monotypic Microsternarchus bilineatus is, in fact, a species complex, with at least five undescribed species in the Negro River basin alone (Maia and Alves-Gomes 2012). The original M. bilineatus, described from a specimen collected in Venezuela, is no longer available in its original fish collection (Cox-Fernandes and Williston 2017) and no tissues or DNA samples are currently available for the type specimen or paratypes. Furthermore, only external morphological traits are not sufficient to discriminate between the different undescribed species found in Brazil. Therefore, until DNA becomes available and/or further systematic studies clarify 
if one of the species found in the Negro River basin is $M$. bilineatus, we opted to consider it as a species to be confirmed (Microsternarchus cf. bilineatus). In addition, we expect no significant differences in the physiological and biochemical responses at the intrageneric level for Microsternarchus.

After capture, fishes were transported to the Laboratory of Behavioral Physiology and Evolution (LFCE) at INPA, in Manaus, where they were divided into groups of approximately 15 individuals and acclimatized in 40-L glass aquaria with constant filtration and aeration. The maintenance water $\left(\mathrm{Na}^{+}\right.$: $1.68 \mathrm{mg} \mathrm{L}^{-1}$; $\mathrm{K}^{+}: 0.41 \mathrm{mg} \mathrm{L}^{-1}$; $\mathrm{Ca}^{2+}$ : $0.07 \mathrm{mg} \mathrm{L}^{-1} ; \mathrm{pH}$ : 6.84; dissolved oxygen: $5.92 \mathrm{mg} \mathrm{L}^{-1}$; conductivity: $20.2 \mu \mathrm{S} \mathrm{cm}^{-1}$, and temperature: $28^{\circ} \mathrm{C}$ ) was obtained from an artesian well on site and kept in a 1,000-L tank with biological filtration and constant aeration before use in the aquaria. Fishes were kept in these conditions for at least seven days before beginning the experiments, and were fed daily with Artemia salina nauplii and Enchytraeus albidus. Daily, food leftovers and waste were vacuumed from the bottom of the aquaria and water was completed to the initial level.

\section{Deltamethrin based pesticide (DBP)}

The DBP was purchased from the commercial formulation Decis ${ }^{\bullet}$ EC (Bayer Vapi PVT LTD, Gujarat, India) with a concentration of $25 \mathrm{~g} \mathrm{~L}^{-1}$ of the insecticide. From the initial concentration, a fresh stock solution was prepared with distilled water to achieve a concentration of $25 \mathrm{mg} \mathrm{L}^{-1}$. The DBP's tested concentrations were defined from the $\mathrm{LC}_{50}$ concentration range obtained for other Amazonian fish species in similar studies (Moraes et al. 2013; Rossi 2013; Souza et al. 2020).

\section{Acute toxicity of DBP}

The median lethal concentration at $96 \mathrm{~h}$ of exposure $\left(\mathrm{LC}_{50}-96 \mathrm{~h}\right.$ of DBP) was determined according to the OECD protocol (OECD 1992). The test was performed using a semi-static system with total water renewal every 24 hours. Feeding was suspended 24 hours before the beginning of the test. After the acclimatization period, fishes were transferred to experimental units containing $2 \mathrm{~L}$ of water and increasing nominal concentrations of $1,2,3,4$ and $5 \mu \mathrm{L} \mathrm{L}^{-1}$ of DBP and a control containing no DBP. Each unit contained seven fishes, and two replicates (2-L units) were used for each concentration, so that 14 fishes were used per treatment. The physical and chemical parameters of water (temperature, electric conductivity, $\mathrm{pH}$, dissolved oxygen, $\mathrm{Na}^{+}, \mathrm{K}^{+}$and $\mathrm{Ca}^{2+}$ ) were measured daily and no significant changes were observed over the experimental period (Table 1). Fishes that died during the experiment were measured, weighed, and immediately frozen in liquid nitrogen. Surviving individuals at the end of the experiment were exposed to hypothermia and euthanized by medullary section. The fish were frozen and later thawed for dissection. Samples of muscle, liver and brain tissue were excised and stored in a freezer at $-80{ }^{\circ} \mathrm{C}$ (Sanyo, Japan) for later enzymatic analysis.

\section{Glutathione-S-transferase (GST; EC 2.5.1.18) assay}

GST activity in liver and muscle tissue was measured by a modification of the method of Keen et al. (1976). The tissue samples were homogenized in phosphate buffer $(100 \mathrm{mM}$; $\mathrm{pH}$ 7.5). The homogenates were centrifuged for 5 minutes at $10,000 \mathrm{xg}$ and the supernatant was used to estimate enzyme activity. Briefly, $30 \mu \mathrm{L}$ of the sample was added in $120 \mu \mathrm{L}$ of assay buffer containing $1 \mathrm{mM}$ reduced glutathione (GSH). The 1-chloro-2, 4-dinitrobenzene (CDNB, $1 \mathrm{mM}$ ) was used as substrate. The change in absorbance was recorded at $340 \mathrm{~nm}$, and enzymatic activity was calculated using a molar extinction coefficient of $9.6 \mathrm{mM}^{-1} \mathrm{~cm}^{-1}$. The enzyme activity was expressed in nmoles $\mathrm{mg}$ protein ${ }^{-1} \mathrm{~min}^{-1}$. The protein concentrations of crude extracts were estimated by the Bradford method (Bradford 1976).

\section{Acetylcholinesterase (AChE; EC 3.1.1.7) assay}

The enzymatic activity of AChE in brain and muscle tissue was determined with few modifications from the original method described by Ellman et al. (1961), using acetylthiocholine iodide (AtCh) as substrate. The tissue samples were homogenized in phosphate buffer $(100 \mathrm{mM}$; $\mathrm{pH} 7.5)$, centrifuged for 5 minutes at $10,000 \mathrm{x}$ g and the supernatant was used to estimate the enzyme activity. Thus, $5 \mu \mathrm{L}$ of sample (homogenized) was used in a microplate containing $120 \mu \mathrm{L}$ of assay buffer. All assays were run under supersaturated substrate concentration (AtCh, $1 \mathrm{mM}$ ). The change in absorbance was recorded at $412 \mathrm{~nm}$ and the

Table 1. Physico-chemical water parameters in the experimental aquaria during the 96-hour exposure of Microsternarchus cf. bilineatus to different concentrations of DBP. Values are the mean \pm SD of measurements made every 24 hours (two aquaria per group).

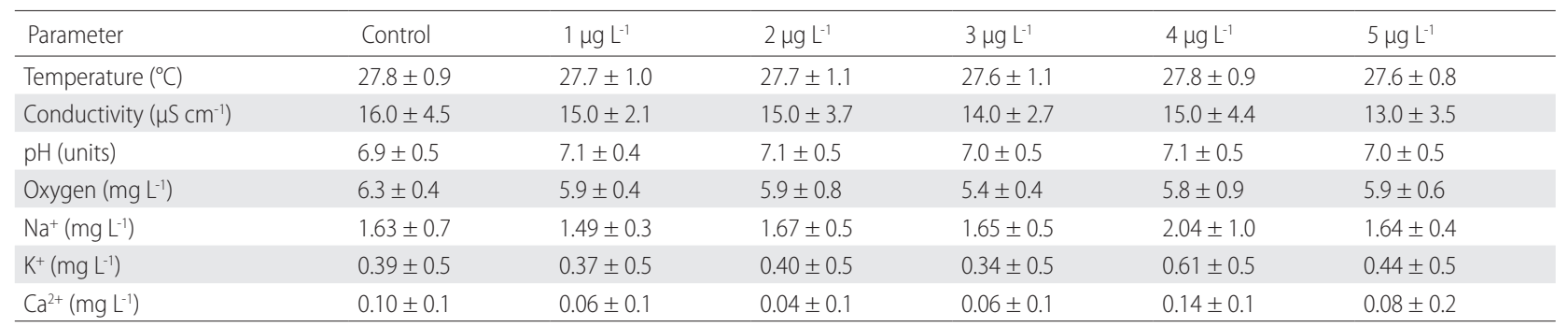


enzymatic activity was calculated using a molar extinction coefficient of $13.6 \mathrm{mM}^{-1} \cdot \mathrm{cm}^{-1}$ (Ellman et al. 1961). The enzyme activity was expressed in nmoles $\mathrm{mg}$ protein ${ }^{-1} \mathrm{~min}^{-1}$.

\section{Data analysis}

The $\mathrm{LC}_{50}$ (at 24, 48, 72 and 96 hours) was calculated with the D-Response Curve (DRR) package from the R program using a logistic model (Ritz et al. 2015). The data for GST and AChE were not normally distributed, so a KruskalWallis analysis was used, followed by Dunn's post-hoc test, which compares all treatment groups with the control. In all performed tests, the accepted significance level was 5\%.

\section{RESULTS}

Overall, 42 deaths were recorded throughout the trial (Table 2), of which 38 were processed for enzymatic assays immediately after death. The other four individuals were processed between two and five hours after death (one from the $5 \mu \mathrm{g} \mathrm{L}-1$ treatment, two for the $3 \mu \mathrm{g} \mathrm{L}^{-1}$ and one for the $\left.4 \mu \mathrm{g} \mathrm{L}^{-1}\right)$.

\section{Acute toxicity of DBP}

Throughout the 96 hours of the test, behavioral changes such as rapid and circular swimming, spasms, permanence on the water surface and increased opercular activity were observed in all groups, except the control group, in which all fishes survived and no behavioral changes were observed. The first death occurred after seven hours in the $5-\mu g \mathrm{~L}^{-1}$ group, and five fish $(71 \%)$ were dead within the first twelve hours. The estimated $\mathrm{LC}_{50}-96 \mathrm{~h}$ was $2.15 \mu \mathrm{g} \mathrm{L}^{-1}$ with a $95 \%$ confidence interval of 1.62-2.67 $\mu \mathrm{g} \mathrm{L}^{-1}$. For the time intervals of 24,48 and $72 \mathrm{~h}$, the estimated $\mathrm{LC}_{50}$ values were $6.12 \mu \mathrm{g} \mathrm{L}{ }^{-1}, 3.21$ $\mu \mathrm{g} \mathrm{L}{ }^{-1}$, and $2.14 \mu \mathrm{g} \mathrm{L}{ }^{-1}$, respectively (Figure 1).

\section{GST and AChE assays}

GST activity in muscle increased for all concentrations tested relative to the control, but was significantly higher only for the concentrations of 2 and $3 \mu \mathrm{g} \mathrm{L}{ }^{-1}$, with average increases of 1.8 and 1.5 times over the control, respectively (Figure 2). There were no significant differences in AChE activity in muscle and nervous tissue, neither in the GST activity in liver (Table 3).

\section{DISCUSSION}

The behavioral responses observed in our fishes exposed to DBP were similar to changes that type II pyrethroid insecticides caused in fishes, such as rapid and circular swimming, which can be related to a direct damage to the nervous system (Glickman et al. 1982; Bradbury et al. 1987; Rice et al. 1997). These changes are commonly reported in pyrethroid-exposed animals and include tremors, loss of balance, and lethargy (Werner and Moran 2008). Our results indicate that DBP is highly toxic to Microsternarchus
Table 2. Mortality of Microsternarchus cf. bilineatus individuals exposed to different concentrations of DBP for 96 hours. Initial numbers corresponded to two replicates (aquaria) with seven fish each (total $\mathrm{N}=14$ ) for each concentration. Final $\mathrm{N}=$ number of individuals alive after 96 hours.

\begin{tabular}{lcc}
\hline DBP concentration & Final N & Mortality (\%) \\
\hline Control & 14 & 0 \\
$1 \mu \mathrm{g} \mathrm{L}^{-1}$ & 12 & 14 \\
$2 \mu \mathrm{g} \mathrm{L}^{-1}$ & 8 & 43 \\
$3 \mu \mathrm{g} \mathrm{L}^{-1}$ & 4 & 71 \\
$4 \mu \mathrm{g} \mathrm{L}^{-1}$ & 3 & 79 \\
$5 \mu \mathrm{g} \mathrm{L}^{-1}$ & 1 & 93 \\
\hline
\end{tabular}

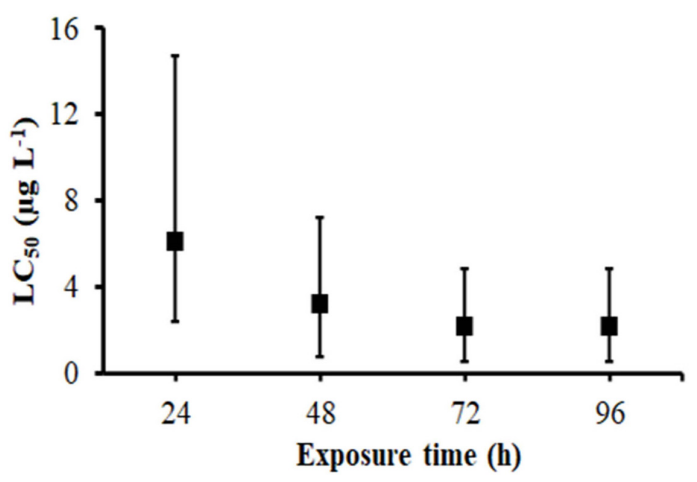

Figure 1. Acute toxicity $\left(L C_{50}\right)$ of DBP on Microsternarchus cf. bilineatus from 24 to 96 hours of exposure.

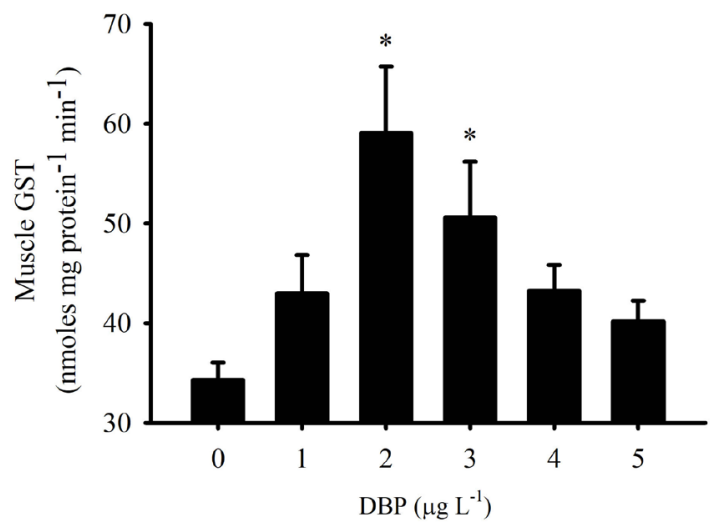

Figure 2. Muscular glutathione-s-transferase (GST) activity in Microsternarchus cf. bilineatus exposed to DBP. * Indicates statistically significant difference compared with the control group $(p<0.05)$.

cf. bilineatus. Based on the $\mathrm{LC}_{50}-96 \mathrm{~h}$ value of $2.15 \mu \mathrm{g} \mathrm{L}-1$, the electric knifefish appears to be even more sensitive to DBP than other Amazonian fish species examined to date. The median values of $\mathrm{LC}_{50}-96 \mathrm{~h}$ for deltamethrin in Carnegiella strigata, Colossoma macropomum, Corydoras schwartzi, Hemigrammus rhodostomus, and Paracheirodon axelrodi ranged from 6.69 to $183.51 \mu \mathrm{g} \mathrm{L}^{-1}$ (Souza et al. 2020). Considering these values, the lethality of deltamethrin appears to be 87 times more toxic in Microsternarchus cf. bilineatus than in Corydoras schwartzi, 
Table 3. Acetylcholinesterase (AChE) and glutathione-s-transferase (GST) enzymatic activity in muscle, nervous and liver tissue of Microsternarchus cf. bilineatus exposed to DBP for 96 hours. Enzyme activity is expressed in nmoles $\mathrm{mg}$ protein ${ }^{-1} \mathrm{~min}^{-1}$. Values are the mean \pm SD of 10 fishes $(\mathrm{N}=10)$

\begin{tabular}{lccc}
\hline \multirow{2}{*}{ DBP } & \multicolumn{3}{c}{ Enzyme } \\
\cline { 2 - 4 } & GST (liver) & AChE (muscle) & AChE (brain) \\
\hline Control & $12.9 \pm 5.9$ & $481.8 \pm 150.0$ & $17.9 \pm 12.9$ \\
$1 \mu \mathrm{g} \mathrm{L}^{-1}$ & $11.1 \pm 9.2$ & $560.3 \pm 167.7$ & $20.5 \pm 9.3$ \\
$2 \mu \mathrm{g} \mathrm{L}^{-1}$ & $11.6 \pm 8.8$ & $600.3 \pm 199.7$ & $26.7 \pm 7.9$ \\
$3 \mu \mathrm{g} \mathrm{L}^{-1}$ & $7.5 \pm 1.7$ & $563.3 \pm 124.3$ & $18.8 \pm 6.4$ \\
$4 \mu \mathrm{g} \mathrm{L}^{-1}$ & $12.6 \pm 10.3$ & $551.7 \pm 193.0$ & $23.1 \pm 7.5$ \\
$5 \mu \mathrm{g} \mathrm{L}^{-1}$ & $16.7 \pm 13.3$ & $576.5 \pm 128.2$ & $17.9 \pm 8.9$ \\
\hline
\end{tabular}

an Amazonian siluriform catfish. The high sensitivity of Microsternarchus cf. bilineatus to DBP is comparable to that found for Brycon amazonicus, for which a $\mathrm{CL}_{50}-96 \mathrm{~h}$ of $2.6 \mu \mathrm{g}$ $\mathrm{L}^{-1}$ was estimated (Moraes et al. 2013). In general, the response of fish to pollutants is influenced by factors such as commercial product formulation and molecule stereochemistry, as well as characteristics of the species such as body size, surface/ volume ratio, feeding behavior and stage of development (Moraes et al. 2013; Haverinen and Vonanen 2016). Species of Microsternarchus have incomplete squamation on the first third of the body, above the lateral line (Cox-Fernandes and Williston 2017), and such direct exposure of the skin to the water may facilitate a higher absorption of pollutants, leading to a higher sensitivity relative to other species.

The increase in muscle GST activity observed in Microsternarchus cf. bilineatus exposed to DBP was similar to the results found in other studies that tested the effect of insecticides as contaminants (Rao 2006; Monteiro et al. 2006; Maduenho and Martinez 2008; Dong et al. 2013). This seems to confirm a specific response to detoxification for DBP, suggesting that muscle GST can play an important role in pollutant elimination from the tissues. Considering that the electric organs of Microsternarchus, and gymnotiforms in general, are embryologically derived from muscle tissue (Kirschbaum and Schwassmann 2008), GST could also provide some sort of specific protection for the electrogenic tissue. An alternative, non-excludent protective action of GST may be linked to its role against products generated by oxidative stress events (Hayes et al. 2005). Many studies have noted the effectiveness of hepatic GST in detoxifying xenobiotics, and the liver is the main source of GST in fishes (Giulio and Hinton 2008). For example, Simonato et al. (2006) reported an increase in hepatic GST activity of Prochilodus lineatus exposed to diesel oil. Braz-Mota et al. (2015) detected a decrease in the activity of hepatic GST of Colossoma macropomum exposed to a glyphosatebased herbicide. However, in $M$. cf. bilineatus the defense mechanisms to GST were detected only in muscle tissue. It can be implied that the GST mechanism of action can occur either by the conjugation of GSH to the xenobiotic or metabolite produced, or by the detoxifying action of GST on oxidative products generated by the DBP poisoning. The fact that we observed a significant increase in the GST activity in muscle in the 2 and $3-\mu g \mathrm{~L}^{-1}$ groups, but not for 4 and $5 \mu \mathrm{L} \mathrm{L}^{-1}$, suggests the existence of more than one metabolic pathway associated with the detoxification by GST in electric fish muscle. Although these alternative mechanisms are presently only hypothetical, a similar type of response has been observed when different species of electric fish were exposed to increasing concentrations of different chemicals. Typically, the physiological effects of extraneous compounds on the EOD patterns within the first two hours of exposure tend to be more conspicuous and statistically significant with intermediate than with higher test concentrations. This pattern was observed for formation water, a byproduct of the oil-drilling industry (Rossoni 2005), for neuroactive drugs (Jesus et al. 2017) and for polluted urban effluents (Nunes 2016). Thus, further studies are necessary to elucidate these patterns in electric fish.

Although we observed no significant changes in AChE activity, in Cyprinus carpio exposed to $2 \mu \mathrm{g} \mathrm{L}^{-1}$ of deltamethrin a $20 \%$ decrease in blood serum AChE activity was reported (Bálint et al. 1995). Szegletes et al. (1995) also found no changes in AChE activity in C. carpio exposed to a concentration of deltamethrin equivalent to $2 \mu \mathrm{g} \mathrm{L} \mathrm{L}^{-1}$, however, they observed a variation in the distribution of AChE molecular forms, indicating that the pesticide can act on AChE even without affecting its activity. Deltamethrin can affect the acetylcholine release in the hippocampus, which could induce a compensatory mechanism of stimulation of $\mathrm{AChE}$ to perform an adaptive up-regulation on acetylcholine hydrolysis (Hossain et al. 2004). However, no direct effect of deltamethrin on AChE activity was observed in rat brains, but observed increased activity of HACU (high-affinity choline uptake) (Hossain et al. 2005). HACU is a $\mathrm{Na}^{+}$dependent choline uptake mechanism which maintains choline regulation in cholinergic neurons and, hence, regulates the acetylcholine synthesis performed by choline acetyltransferase, showing that deltamethrin is related to cholinergic processes, but not directly to AChE enzyme activity (Hossain et al. 2005). In the light of the available data, the interaction between pyrethroids and acetylcholinesterase remains unclear and should be further investigated.

\section{CONCLUSIONS}

Microsternarchus cf. bilineatus was shown to be highly sensitive to the DBP tested, with a $\mathrm{LC}_{50}-96 \mathrm{~h}$ of $2.15 \mu \mathrm{g} \mathrm{L}^{-1}$, the lowest concentration reported for an Amazonian teleost to date. AChE and hepatic GST were not considered good 
biochemical markers for $M$. cf. bilineatus exposed to DBP as they were not significantly affected by the tested DBP concentrations and exposure periods. On the other hand, muscle GST increased significantly in fishes submitted to DBP concentrations of 2 and $3 \mu \mathrm{g} \mathrm{L} \mathrm{L}^{-1}$, probably as a mechanism for pollutant elimination in this tissue, by xenobiotic detoxification through conjugation, or by the action of GST on products generated by oxidative stress. The lack of increase of GST activity for the higher concentrations ( 4 and $5 \mu \mathrm{L} \mathrm{L}^{-1}$ ), may owe to the existence of more than one internal pathway to deal with physiological and biochemical stress in this species, possibly in association with exposition time. Our findings raise interesting questions regarding the action of pyrethroids on other physiological mechanisms of this electric fish species. For instance, the effect of DBP on the physiology of the electric organ, since electrogenic cells are rich in $\mathrm{Na}^{+}$channels and the regular functioning of these channels controls the passage of electrical impulses that will generate the EODs in these fishes.

\section{ACKNOWLEDGMENTS}

The authors would like to express their gratitude to two anonymous referees for helpful criticism and suggestions on the text, to Rubia Neris Machado (Universidade Federal do Amazonas - UFAM) for supporting biochemical analysis, to the Conselho Nacional de Desenvolvimento Científico e Tecnológico (CNPq/Brazil) for the research fellowship to JLM, and the Master's scholarship to VSC, and to Fundaçáo de Amparo à Pesquisa do Estado do Amazonas (FAPEAM) for the research grant $0600360 / 2013$ to JAAG.

\section{REFERENCES}

Alves-Gomes, J.A. 1997. Informações preliminares sobre a bioecologia de peixes elétricos (Ordem Gymnotiformes) em Roraima. In: Barbosa, R.I.; Ferreira, E J.G.; Castellón, E.G. (Org.). Homem, Ambiente e Ecologia no Estado do Roraima. Editora INPA, Manaus, p.509-555.

Alves-Gomes, J.A.; Ortí, G.; Haygood, M.; Heiligenberg, W.; Meyer, A. 1995. Phylogenetic analysis of the South American electric fishes (order Gymnotiformes) and the evolution of their electrogenic system: a synthesis based on morphology, electrophysiology, and mitochondrial sequence data. Molecular Biology and Evolution, 12: 298-318.

Alves-Gomes, J.A. 2001. The evolution of electroreception and bioelectrogenesis in teleost fish: a phylogenetic perspective. Journal of Fish Biology, 58: 1489-1511.

Bálint, T.; Szegletes, T.; Szegletes, Z.S.; Halasy, K.; Nemcsók, J. 1995. Biochemical and subcellular changes in carp exposed to the organophosphorus methidathion and the pyrethroid deltamethrin. Aquatic Toxicology, 33: 279-295.

Bradbury, S.P.; Mckim, J.M.; Coats, J.R. 1987. Physiological response of rainbow trout (Salmo gairdneri) to acute fenvalerate intoxication. Pesticide Biochemistry and Physiology, 27: 275-288.
Bradford, M.M. 1976. A rapid and sensitive method for the quantification of microgram quantities of protein utilizing the protein-dye binding. Analytical Biochemistry, 72: 248-254.

Braz-Mota, S.; Sadauskas-Henrique, H.; Duarte, R.M.; Val, A.L.; Almeida-Val, V.M.F. 2015. Roundup exposure promotes gills and liver impairments, DNA damage and inhibition of brain cholinergic activity in the Amazon teleost fish Colossoma macropomum. Chemosphere, 135: 53-60.

Bullock, T.H. 1982. Electroreception. Annual Review of Neuroscience, 5: 121-170.

Bullock, T.H.; Fernandes-Souza, N.; Graf, W.; Hellingenberg, W.; Langner, G.; Meyer, D.L.; et al. 1979. Aspectos do uso da descarga do órgão elétrico eletrorecepção nos Gymnotoidei e outros peixes amazônicos. Acta Amazonica, 9: 549-572.

Cox-Fernandes, C.; Williston, A. 2017. Redescription of Microsternarchus bilineatus (Fernández-Yépez, 1968) (Gymnotiformes: Hypopomidae, Microsternarchini), with the designation of a neotype. Proceedings of the Academy of Natural Sciences of Philadelphia. 165: 105-115.

Dong, M.; Zhu, L.; Shao, B.; Zhu, S.; Wang, J.; Xie, H.; et al. 2013. The effects of endosulfan on cytochrome P450 enzymes and glutathione-s-transferases in zebrafish (Danio rerio) livers. Ecotoxicology and Environmental Safety, 92: 1-9.

Elia, A.C.; Giorda, F.; Pacini, N.; Dorr, A.J.M.; Scanzio, T.; Prearo, M. 2017. Subacute toxicity effects of deltamethrin on oxidative stress markers in rainbow trout. Journal Aquatic Animal Health, 29: $165-172$.

Ellman, G.L.; Courtney, K.D.; Andres, J.V.; Featherstone, R.M. 1961. A new and rapid colorimetric determination of acetylcholinesterase activity. Biochemical Pharmacology, 7: 88-95.

Ferreira, D.J.S. 2009. Utilização de Microsternarchus bilineatus (Ostariophysi, Gymnotiformes, Hypopomidae) como biomonitor: o efeito de combustíveis automotivos derivados do petróleo na descarga do órgão elétrico. Master's thesis, Instituto Nacional de Pesquisas da Amazônia, Brazil. 67p. (https://bdtd. inpa.gov.br/handle/tede/1412)

Ferreira, M.; Jesus, I.; Feldberg, E.; Alves-Gomes, J.A. 2015. Neotropical electric fishes (Gymnotiformes) as model organisms for bioassays. Journal of Coast Life Medicine, 3: 253-258.

Ferreira, D.J.S. 2016. Efeito de combustíveis derivados do petróleo na descarga do órgáo elétrico de Parapterontus hasemani (Ellis 1913) (Ostariophysi, Gymnotiformes). Doctoral thesis, Instituto Nacional de Pesquisas da Amazônia, Brazil. 147p. (https://bdtd. inpa.gov.br/handle/tede/2402)

Giulio, R.T.; Hinton, D.E. 2008. The Toxicology of Fishes. 1st ed. Taylor and Francis Group, Boca Raton, 1071p.

Glickman, A.H.; Weitman, S.D.; Lech, J.J. 1982. Differential toxicity of trans-permethrin to rainbow trout and mice. I. Role of biotransformation. Toxicology and Applied Pharmacology, 66: 153-161.

Haverinen, J.; Vornanen, M. 2016. Deltamethrin is toxic to the fish (crucian carp, Carassius carassius) heart. Pesticide Biochemistry and Physiology, 129: 36-42. 
Hagedorn, M. 1986. The ecology, courtship and mating of gymnotiform fish. In: Bullock, T.H.; Heiligenberg, W. (Ed.). Electroreception. Wiley, New York, p.497-527.

Hayes, J.D.; Flanagan, J.U.; Jowsey, I.R. 2005. Glutathione transferases. Annual Review of Pharmacology and Toxicology, 45: 51-88.

Hopkins, C.D. 1974. Electric communication in fish. American Scientist, 62: 426-437.

Hossain, M.M.; Suzuki, T.; Sato, I.; Takewaki, T.; Suzuki, K.; Kobayashi, H. 2004. The modulatory effect of pyrethroids on acetylcholine release in the hippocampus of freely moving rats. Neurotoxicology, 25: 825-833.

Hossain, M.M.; Suzuki, T.; Sato, I.; Takewaki, T.; Suzuki, K.; Kobayashi, H. 2005. Neuromechanical effects of pyrethroids, allethrin, cyhalothrin and deltamethrin on the cholinergic processes in rat brain. Life Sciences, 77: 795-807.

Jesus, I.S.; Ferreira, M.; Silva-Junior, U.L.; Alves-Gomes, J.A. 2017. Effects of neuroactive drugs in the discharge patterns of Microsternarchus (Hypopomidae: Gymnotiformes) electric organ. Zebrafish, 14: 526-535.

Keen, J.H.; Habig, W.H.; Jakobi, W.B. 1976. Mechanism for the several activities of the glutathione-S-transferases. Journal of Biological Chemistry, 251: 6183-6188.

Kirschbaum, F.; Schwassmann, H.O. 2008. Ontogeny and evolution of electric organs in gymnotiform fish. Journal of Physiology Paris, 102: 347-356.

Maia, C.R.; Alves-Gomes, J.A. 2012. Utilização do código de barras de DNA na estimativa de diversidade de peixes elétricos do gênero Microsternarchus (Ostariophysi: Gymnotiformes) na bacia do Rio Negro, Amazonas. In: Souza, L.A.G.; Castellón, E.G. (Ed.). Projeto Fronteira - Desvendando as Fronteiras do Conhecimento na Região Amazônica do Alto Rio Negro. Editora INPA, Manaus, p.185-202.

Maduenho, L.P.; Martinez, C.B.R. 2008. Acute effects of diflubenzuron on the freshwater fish Prochilodus lineatus. Comparative Biochemistry and Physiology Part C - Toxicology \& Pharmacology, 148: 265-272.

Marrero, C.; Taphorn, D. 1991. Notas sobre la historia natural y la distribution de los peces Gymnotiformes en la cuenca del río Apure y otros rios de la Orinoquia. Biollania, 8: 123-142.

Moraes, F.D.; Venturini, F.P.; Cortella, L.R.X.; Rossi, P.A.; Moraes, G. 2013. Acute toxicity of pyrethroid-based insecticides in the Neotropical freshwater fish Brycon amazonicus. Ecotoxicology and Environmental Contamination, 8: 59-64.

Moraes, F.; Maximino, C.; Carvalho, F.; Alves, A.; Paula, H.; Junior, A. 2013. Effects of methylmercury on electric organ discharges in the weak electric fish Gymnotus sylvius. Psychology \& Neuroscience, 6: 123-127.

Monteiro, D.A.; Almeida, J.A.; Rantin, F.T.; Kalinin, A.L. 2006. Oxidative stress biomarkers in the freshwater characid fish, Brycon cephalus, exposed to organophosphorus insecticide Folisuper 600 (methyl parathion). Comparative Biochemistry and Physiology Part C - Toxicology \& Pharmacology, 143: 141-149.

Nunes, D.M.F. 2016. O efeito sinergético de poluentes urbanos nos padrôes de descarga de Microsternarchus sp. (Gymnotiformes).
Master's thesis, Instituto Nacional de Pesquisas da Amazônia, Brazil, 50p. (https://bdtd.inpa.gov.br/handle/tede/2285)

OECD. 1992. OECD Guideline for Testing of Chemicals, 203. Fish, Acute Toxicity Test. OECD, Paris. (https://www.oecd. $\mathrm{org} /$ chemicalsafety/risk-assessment/1948241.pdf). Accessed on 09 Dec 2015.

Pimpão, C.T.; Zampronio, A.R.; Silva de Assis, H.C. 2007. Effects of deltamethrin on hematological parameters and enzymatic activity in Ancistrus multispinis (Pisces, Teleostei). Pesticide Biochemistry and Physiology, 88: 122-127.

Rao, J.V. 2006. Toxic effects of novel organophosphorus insecticide (RPR-V) on certain biochemical parameters of euryhaline fish, Oreochromis mossambicus. Pesticide Biochemistry and Physiology, 86: $78-84$.

Rice, P.J.; Drewes, C.D.; Klubertanz, T.M.; Bradbury, S.P.; Coats, J.R. 1997. Acute toxicity and behavioral effects of chlorpyrifos, permethrin, phenol, strychnine, and 2,4-dinitrophenol to 30-day-old Japanese medaka (Oryzias latipes). Environmental Toxicology and Chemistry, 16: 696-704.

Rossi, P.A. 2013. Alteraçôes bioquímico-fisiológicas em pacu (Piaractus mesopotamicus Holmberg 1887) exposto a um inseticida a base de deltametrina. Master's thesis, Universidade Federal de São Carlos, Brazil, 89p. (https://repositorio.ufscar. $\mathrm{br} /$ handle/ufscar/5520)

Rossoni, D.M. 2005. A utilização das descargas dos órgãos elétricos de Apteronotus hasemani e Apteronotus bonapartii (Apteronotidae, Gymnotiformes) como bioindicadores em ambientes aquáticos. Master's thesis, Instituto Nacional de Pesquisas da Amazônia, Brazil, 86p. (https://bdtd.inpa.gov.br/handle/tede/766)

Ritz, C.; Baty, F.; Streibig, J.C.; Gerhard, D. 2015. Dose-Response Analysis Using R. PLoS ONE. 10: e0146021.

Santos, M.A.T.; Areas, M.A.; Reyes, F.G.R. 2007. Piretróides - uma visão geral. Alimentos e Nutrição, 18: 339-349.

Soares, C.A.P. 2016. Estudo de indicadores de estresse em Brycon amazonicus (matrinxã) exposto a deltametrina (Keshet $\left.{ }^{\circ}\right)$. Master's thesis, Universidade Federal de São Carlos, Brazil. 70p. (https:// repositorio.ufscar.br/handle/ufscar/8473)

Soreq, H.; Seidman, S. 2001. Acetylcholinesterase - new roles for an old factor. Nature Reviews Neuroscience, 2: 294-302.

Souza, T.C.; Silva, S.L.R.; Marcon, J.L.; Waichman, A.V. 2020. Acute toxicity of deltamethrin to Amazonian freshwater fish. Toxicology Environmental Health Sciences, 12: 149-155.

Simonato, J.D.; Guedes, C.L.; Martinez, C.B. 2008. Biochemical, physiological, and histological changes in the neotropical fish Prochilodus lineatus exposed to diesel oil. Ecotoxicology and Environmental Safety, 69: 112-120.

Szegletes, T.; Balint, T.; Szegletes, Z.; Nemcsok, J. 1995. In vivo effects of deltamethrin exposure on activity and distribution of molecular forms of carp AChE. Ecotoxicology and Environmental Safety, 31: 258-263.

Tu, H.T.; Silvestre, F.; Meulder, B.D.; Thome, J.P.; Phuong, N.T.; Kestemont, P. 2012. Combined effects of deltamethrin, temperature and salinity on oxidative stress biomarkers and acetylcholinesterase activity in the black tiger shrimp (Penaeus monodon). Chemosphere, 86: 83-91. 
Waichman, A.V.; Römbke, J.; Ribeiro, M.O.A.; Nina, N.C.S. 2002. Use and fate of pesticides in the Amazon State, Brazil: Risk to human health and the environment. Environmental Science and Pollution Research, 9: 423-428.

Waichman, A.V.; Eve, E.; Nina, N.C.S. 2007. Do farmers understand the information displayed on pesticide product labels? A question to reduce pesticides exposure and risk of poisoning the Brazilian Amazon. Crop Protection, 26: 576-583.

Werner, I.; Moran, K. 2008. Effects of pyrethroid insecticides on aquatic organisms. In: Gan, J.; Spurlock, F.; Hendley, P.; Weston, D.P. (Ed.). Synthetic Pyrethroids. Occurrence and Behavior in Aquatic Environments, ACS Symposium Series v. 991, Chapter 14, ACS Publications, Washington D.C., p.310-334.

RECEIVED: $25 / 10 / 2019$

ACCEPTED: 24/08/2020

ASSOCIATE EDITOR: Carlos J. Sousa Passos 